\title{
Impact of non-adherent Ibuprofen foam dressing in the lives of patients with venous ulcers
}

\section{Impacto do curativo de espuma não aderente com Ibuprofeno na vida dos pacientes com úlcera venosa}

\author{
Geraldo Magela Salomépi ' Lydia Masako Ferreira, TCBC-SP¹.
}

\begin{abstract}
A B S T R A C T
Objective: to evaluate pain in patients with lower limb venous ulcer who used non-adherent lbuprofen foam dressing (IFD). Methods: we conducted a prospective study of patients with lower limb venous ulcers treated from April 2013 to August 2014. We used the Numerical Scale and McGill Pain Questionnaire, performing the assessments at the moment of inclusion of the patient in the study and every eight days thereafter, totaling five consultations. We divided the patients into two groups: 40 in the Study Group (SG), who were treated with IFD, and 40 in the Control Group (CG), treated with primary dressing, according to tissue type and exudate. Results: at the first consultation, patients from both groups reported intense pain. On the fifth day, SG patients reported no pain and the majority of CG reported moderate pain. Regarding the McGill Pain Questionnaire, most patients of both groups reported sensations related to sensory, affective, evaluative and miscellaneous descriptors at the beginning of data collection; after the second assessment, there was slight improvement among the patients in the SG. After the third consultation, they no longer reported the mentioned descriptors. CG patients displayed all the sensations of these descriptors until the fifth visit. Conclusion: non-adherent Ibuprofen foam dressing is effective in reducing the pain of patients with venous ulcers.
\end{abstract}

Keywords: Varicose Ulcer. Lower Extremity. Pain Measurement. Ibuprofen. Quality of life. Patient-Centered Care.

\section{INTRODUCTION}

$V$ enous ulcers are a consequence of chronic venous insufficiency, due to venous hypertension caused by valvular incompetence of the superficial and deep veins, venous obstruction or a combination of these factors ${ }^{1,2}$. They most commonly affect the lower limbs and commit about $5 \%$ of the adult population in Western countries, with a prevalence of $0.3 \%$. Their occurrence increases with age, being higher than $4 \%$ in individuals over 65 years old ${ }^{1,3}$. They may present exudate and odor, with the need to change dressings several times a day, with an impact on the lifestyle. It is common for the patient to present frustration and hopelessness related to treatment, since some of these lesions can take months to heal| ${ }^{4-7}$. They cause pain, edema, loss of mobility and withdrawal from work, often leading to disability retirement. As a consequence of the pain, which aggravates or causes difficulty in locomotion, and restriction of activities of daily living and leisure, venous ulcers can lead to changes in quality of life and self-esteem, and determine anxiety and depression, which may contribute to delay the ulcer healing process ${ }^{8-15}$.

The Ibuprofen foam dressing (IFD) is a non-adherent dressing, formed by foam attached to a semipermeable polyurethane film that allows Ibuprofen release into the wound by the presence of fluids or exudate. It is an innovative technology that promotes better control of the exudate, ensures a minimum risk of leakage or maceration of the skin, brings pain relief during the use time and during its exchange and promotes a humid environment ${ }^{16-18}$.

This study aimed to evaluate the impact of non-adherent Ibuprofen foam dressing in pain control of patients with venous ulcers.

\section{METHODS}

We carried out a controlled, randomized, analytical and prospective study at the São João Ambulatory of the Dr. José Antônio Garcia Coutinho

1 - Sapucaí Valley University, Professional Master's Degree in Applied Health Sciences, Pouso Alegre, MG, Brazil. 
Faculty of Health Sciences, after approval by the Ethics in Research Committee under number 534,263.

We studied 80 patients, divided into two groups with 40 patients each: Study Group (SG), treated with IFD, and Control Group (CG), treated with primary dressing, according to tissue type and exudate. Inclusion criteria were: age equal or above 18 years, ankle/arm ratio between 1.0 and 1.4 , patients who were taking pain medication and who were not being treated with compressive therapy. Exclusion criteria were: patients whose wounds presented clinical signs of infection, allergy to Ibuprofen or presence of erysipelas adjacent to the lesion. We excluded patients who missed the outpatient visits, those who were taking pain medication during the study and patients who, during the study, showed clinical signs of infection or allergy.

We performed the study from April 2013 to August 2014. We collected the first data at the time of inclusion of the patient in the study, and then every eight days, totaling five visits. In these consultations, we evaluated the wound and changed the primary dressing, but the patients were instructed to change the secondary dressing whenever saturation occurred.

We randomized patients by sealed and opaque envelopes, which were stored at the randomization central. An independent individual generated a sequence of random numbers, placing them one by one in the sealed envelopes. Patients were drawn consecutively, through withdrawal of the envelope and allocation in one of the groups.

Participants answered a questionnaire on sociodemographic and clinical data. To quantify the intensity of pain, we used the Numerical Pain Scale, graded from 0 to 10 , where 0 means absence of pain and 10, the worst pain eve felt. Pain intensity was classified as painless (0), mild pain (1-3), moderate (46), and severe (7-10) 19,20 .

We evaluated the pain quality with the application of the McGill Pain Questionnaire. This questionnaire consists of words known as descriptors, as they describe the sensation of pain that the patient may be feeling. The descriptors are organized into four major groups and into 20 subgroups. Each set of subgroups evaluates a group. The descriptors cover the areas: sensory (subgroup of 1 to 10), affective (subgroup of 11 to 15), evaluative (subgroup 16) and miscellaneous (subgroup of 17 to 20) ${ }^{19,20}$. The sensorydiscriminative group (subgroups 1 to 10) refers to the pain's mechanical, thermal, vivid and spatial properties; the affective-motivational group (subgroups 11 to 15) describes the affective dimension in the aspects of tension, fear and neurovegetative responses; The descriptors of the cognitive-evaluative component (subgroup 16) allow the patient to express the overall evaluation of the pain experience. Subgroups 17 through 20 comprise miscellaneous items. Each subgroup consists of two to six qualitatively similar descriptors, but with nuances that make them different in terms of magnitude. Thus, for each descriptor a number indicates its intensity.

The McGill questionnaire can render the number of descriptors chosen and the pain index. The number of descriptors chosen corresponds to the words that the patient chose to explain the pain. The highest possible value is 20 , since the patient can only choose at most one word per subgroup. The pain index is obtained with the sum of the intensity values of the chosen descriptors. These indices can be obtained in total and for each of the four components of the questionnaire: sensitive, affective, evaluative and miscellaneous subgroup.

We performed the statistical analysis with SPSS 11.5, using the Mann-Whitney and Chi-square tests. For all statistical tests, we considered significance levels of $5 \%(p \leq 0.05)$.

\section{RESULTS}

The sociodemographic variables of the participants can be seen in table 1 . We verified that the majority of the participants of both groups were white, female, aged over 60, retired and smokers. With regard to schooling, 18 participants (45\%) of the SG were illiterate and 29 patients (72.50\%) of the CG had only elementary education.

Regarding the lesion, table 2 shows that the majority of patients in both groups had lived with the ulcer for six to ten years and the lesions presented exudate and odor. 
Table 1. Sociodemographic variables of the study participants.

\begin{tabular}{|c|c|c|c|c|c|}
\hline \multirow[t]{3}{*}{ Variables } & \multicolumn{4}{|c|}{ Group } & \multirow{3}{*}{$\mathrm{p}$-value } \\
\hline & \multicolumn{2}{|c|}{ Study Group } & \multicolumn{2}{|c|}{ Control Group } & \\
\hline & $\mathrm{n}$ & $\%$ & $\mathrm{n}$ & $\%$ & \\
\hline \multicolumn{6}{|l|}{ Race } \\
\hline White & 33 & 82.50 & 28 & 70.00 & \\
\hline Black & 07 & 17.50 & 12 & 30.00 & * 0.001 \\
\hline Total & 40 & 100.00 & 40 & 100.00 & \\
\hline \multicolumn{6}{|l|}{ Age Group } \\
\hline$<$ of 50 years & 01 & 2.50 & 2 & 5.00 & \\
\hline 50 to 59 years & 03 & 7.50 & 01 & 2.50 & \\
\hline 60 to 69 years & 31 & 77.50 & 35 & 87.50 & * 0.002 \\
\hline 70 to 79 years & 05 & 12.50 & 01 & 2.50 & \\
\hline$>$ of 80 years & 00 & 00 & 01 & 2.50 & \\
\hline Total & 40 & 100.00 & 40 & 100.00 & \\
\hline \multicolumn{6}{|l|}{ Gender } \\
\hline Female & 28 & 70.00 & 26 & 65.00 & \\
\hline Male & 12 & 30.00 & 14 & 35.00 & * 0.003 \\
\hline Total & 40 & 100.00 & 40 & 100.00 & \\
\hline \multicolumn{6}{|l|}{ Smoker } \\
\hline No & 11 & 27.50 & 11 & 27.50 & \\
\hline Yes & 29 & 72.50 & 29 & 72.50 & * 0.003 \\
\hline Total & 40 & 100.00 & 40 & 100.00 & \\
\hline \multicolumn{6}{|l|}{ Schooling } \\
\hline Literate & 00 & 00 & 18 & 45.00 & \\
\hline Complete elementary school & 04 & 10 & 01 & 2.50 & \\
\hline Incomplete elementary school & 29 & 72.50 & 13 & 32.50 & \\
\hline Incomplete high school & 02 & 5.00 & 03 & 7.50 & 0.067 \\
\hline Complete high school & 04 & 10.00 & 05 & 12.50 & \\
\hline College level & 01 & 2.50 & 00 & 00 & \\
\hline Total & 40 & 100.00 & 40 & 100.00 & \\
\hline \multicolumn{6}{|l|}{ Profession } \\
\hline Unemployed & 00 & 00 & 05 & 12.50 & \\
\hline Retired & 22 & 55.00 & 26 & 65.00 & \\
\hline Housewife & 10 & 25.00 & 09 & 22.50 & \\
\hline Housekeeper & 06 & 15.00 & 00 & 00 & 0.087 \\
\hline Caregiver & 01 & 2.50 & 00 & 00 & \\
\hline Craftsman & 01 & 2.50 & 00 & 00 & \\
\hline Total & 40 & 100.00 & 40 & 100.00 & \\
\hline
\end{tabular}

Chi-square test of Pearson; * Level of statistical significance $p \leq 0.05$. 
Table 2. Wound-related variables.

\begin{tabular}{|c|c|c|c|c|c|}
\hline \multirow[t]{3}{*}{ Variables } & \multicolumn{4}{|c|}{ Group } & \multirow{3}{*}{$\mathrm{p}$-value } \\
\hline & \multicolumn{2}{|c|}{ Study Group } & \multicolumn{2}{|c|}{ Control Group } & \\
\hline & $n$ & $\%$ & $n$ & $\%$ & \\
\hline \multicolumn{6}{|l|}{ Time of injury } \\
\hline$<$ of 12 months & 04 & 10.00 & 02 & 5.00 & \\
\hline 1 to 5 years & 06 & 15.00 & 03 & 7.50 & \\
\hline 6 to 10 years & 25 & 62.50 & 31 & 77.50 & * 0.001 \\
\hline$>$ from 11 years & 05 & 12.50 & 04 & 10.00 & \\
\hline Total & 40 & 100.00 & 40 & 100.00 & \\
\hline \multicolumn{6}{|l|}{ Exudate } \\
\hline Yes & 22 & 55.00 & 32 & 80.00 & \\
\hline No & 18 & 45.00 & 08 & 20.00 & * 0.001 \\
\hline Total & 40 & 100.00 & 40 & 100.00 & \\
\hline \multicolumn{6}{|l|}{ Odor } \\
\hline Yes & 23 & 57.50 & 31 & 77.50 & \\
\hline No & 17 & 42.50 & 09 & 22.50 & * 0.001 \\
\hline Total & 40 & 100.00 & 40 & 100.00 & \\
\hline
\end{tabular}

Chi-square test of Pearson; * Level of statistical significance $p \leq 0.05$.

Table 3 shows that the majority of patients in both groups had diabetes mellitus, hypertension, but no heart disease.

Table 4 shows that in the first data collection, patients in both groups reported intense pain; in the second, the majority of SG patients reported moderate pain. In CG, 20 (50\%) reported moderate pain and 19 (47.50\%) had severe pain. In the third data collection, the majority of SG patients reported mild pain and CG patients reported moderate pain. In the fourth assessment, most SG patients reported no pain. In CG, most reported moderate pain. At the fifth visit, most SG patients reported no pain. In CG, most reported moderate pain.

Table 5 shows that the majority of patients in both groups reported sensory, affective, evaluative and miscellaneous descriptors. CG individuals continued to report these descriptors until the fifth visit, with a slight improvement, but SG patients showed significant improvement during the first and even in the fifth data collection.

\section{DISCUSSION}

In Brazil, chronic venous disease is the 14th cause of temporary withdrawal from work. These data represent a serious public health problem, affecting several age groups, different ethnicities, both genders, reflecting public spending and interference in the quality of life of patients and their families. It was found that the majority of the patients were smokers and with a low level of education, data that are similar to those of other studies ${ }^{5-7,17,21,22}$. Among the study participants, women predominated. It is inferred that the occurrence of venous ulcer in the female gender is associated with hormonal factors, pregnancy, puerperium and the higher incidence of varicose veins, which may favor the onset of chronic venous insufficiency. This predominance is also due in part to female longevity, since up to the age of 40 the number of cases is evenly distributed between both genders $23-25$ 
Table 3. Disease-related variables.

\begin{tabular}{|c|c|c|c|c|c|}
\hline \multirow[t]{3}{*}{ Variables } & \multicolumn{4}{|c|}{ Group } & \multirow{3}{*}{ p-value } \\
\hline & \multicolumn{2}{|c|}{ Study Group } & \multicolumn{2}{|c|}{ Control Group } & \\
\hline & $n$ & $\%$ & $\mathrm{n}$ & $\%$ & \\
\hline \multicolumn{6}{|l|}{ Diabetes Mellitus } \\
\hline Yes & 08 & 20 & 03 & 7.50 & \\
\hline No & 32 & 80 & 37 & 92.50 & * 0.001 \\
\hline Total & 40 & 100.00 & 40 & 100.00 & \\
\hline \multicolumn{6}{|l|}{ Arterial Hypertension } \\
\hline Yes & 14 & 35 & 20 & 50 & \\
\hline No & 26 & 65 & 20 & 50 & * 0.001 \\
\hline Total & 40 & 100.00 & 40 & 100.00 & \\
\hline \multicolumn{6}{|l|}{ Cardiopathy } \\
\hline Yes & 10 & 25 & 05 & 12.50 & \\
\hline No & 30 & 75 & 35 & 87.50 & * 0.001 \\
\hline Total & 40 & 100.00 & 40 & 100.00 & \\
\hline
\end{tabular}

Chi-square test of Pearson; * Level of statistical significance $p \leq 0.05$.

With regard to smoking, it impairs tissue oxygenation, decreases the body's resistance, makes it more susceptible to infections and delays healing. In addition, smoking alters collagen synthesis, hampering wound healing. Nicotine produces vasoconstriction, which increases the risk of ischemia and the development of ulcers, and ulcers, when already present, have difficulty in healing. In these cases, the cellular process is interrupted and abnormal functions of the healing process derive from systemic or local factors, or both ${ }^{26}$.

Wound pain results from tissue injury and the perception of pain depends on numerous factors related to the patient, type of wound, quantity and intensity of external stimuli19,20. The skin is richly innervated, which gives it the ability to capture various types of stimuli, and the presence of infection and necrosis aggravates the wounds' painful process. Chronic pain can be considered as the perpetuation of acute pain, has no biological function of alertness and generates suffering. In general, neurovegetative responses such as those found in acute pain do not occur, resulting from the adaptation of neuronal systems ${ }^{27}$.
Pain is one of the main causes of suffering for any sick person. National and international studies report that approximately $80 \%$ of people's demand for health services is pain-motivated. Chronic pain affects 30 to $40 \%$ of Brazilians and is the main cause of absenteeism, sick leave, health-related retirements, workers' compensation and low labor productivity ${ }^{28,29}$. Pain is a very common symptom in patients with venous ulcers and its prevalence varies between 80 and $96 \%$ in this group. It may be persistent and/or exacerbated during dressing changes. Pain can also negatively influence healing, as the painful stimulus is associated with the release of inflammatory mediators, which potentially reduce tissue repair and regeneration ${ }^{16,30-32}$.

In the present study, all patients in the two groups reported severe pain at the beginning of data collection, but the participants of the SG, who were treated with the non-adherent Ibuprofen foam dressing, showed significant pain improvement in the second week of treatment. Regarding the CG, after the fourth consultation, the patients reported moderate pain, while SG patients reported no pain. 
Table 4. Total score of the numerical pain scale.

\begin{tabular}{|c|c|c|c|c|c|}
\hline \multirow{3}{*}{ Numeric pain scale } & \multicolumn{4}{|c|}{ Group } & \multirow{3}{*}{ p-value } \\
\hline & \multicolumn{2}{|c|}{ Study Group } & \multicolumn{2}{|c|}{ Control Group } & \\
\hline & $\mathrm{n}$ & $\%$ & $\mathrm{n}$ & $\%$ & \\
\hline \multicolumn{6}{|l|}{$1^{\text {st }}$ Assessment } \\
\hline 0 (absence of pain) & 00 & 00 & 00 & 00 & \multirow{7}{*}{$* 0.001$} \\
\hline 1 to 3 (mild) & 00 & 00 & 02 & 5.0 & \\
\hline 4 to 6 (moderate) & 06 & 15.00 & 05 & 12.50 & \\
\hline 7 to 10 (intense) & 34 & 85.00 & 33 & 82.50 & \\
\hline Total & 40 & 100.00 & 40 & 100.00 & \\
\hline Average & 7.88 & & 8.25 & & \\
\hline Standard deviation & 1.871 & & 2.619 & & \\
\hline \multicolumn{6}{|l|}{$2^{\text {nd }}$ Assessment } \\
\hline 0 (absence of pain) & 00 & 00 & 00 & 00 & \multirow{7}{*}{ * 0.001} \\
\hline 1 to 3 (mild) & 07 & 17.50 & 01 & 2.50 & \\
\hline 4 to 6 (moderate) & 30 & 75.00 & 20 & 50.00 & \\
\hline 7 to 10 (intense) & 03 & 7.50 & 19 & 47.50 & \\
\hline Total & 40 & 100.00 & 40 & 100.00 & \\
\hline Average & 4.53 & & 6.80 & & \\
\hline Standard deviation & 1.320 & & 2.451 & & \\
\hline \multicolumn{6}{|l|}{$3^{\text {rd }}$ Assessment } \\
\hline 0 (absence of pain) & 00 & 00 & 00 & 00 & \multirow{7}{*}{$* 0.001$} \\
\hline 1 to 3 (mild) & 38 & 95.00 & 01 & 2.50 & \\
\hline 4 to 6 (moderate) & 02 & 5.00 & 26 & 65.00 & \\
\hline 7 to 10 (intense) & 00 & 00 & 13 & 32.50 & \\
\hline Total & 40 & 100.00 & 40 & 100.00 & \\
\hline Average & 1.90 & & 6.12 & & \\
\hline Standard deviation & 0.900 & & 2.178 & & \\
\hline \multicolumn{6}{|l|}{$4^{\text {th }}$ Assessment } \\
\hline 0 (absence of pain) & 34 & 85.00 & 00 & 00 & \multirow{7}{*}{ * 0.001} \\
\hline 1 to 3 (mild) & 06 & 15.00 & 02 & 5.0 & \\
\hline 4 to 6 (moderate) & 00 & 00 & 28 & 70.00 & \\
\hline 7 to 10 (intense) & 00 & 00 & 10 & 25.00 & \\
\hline Total & 40 & 100.00 & 40 & 100.00 & \\
\hline Average & 0.15 & & 5.18 & & \\
\hline Standard deviation & 0.362 & & 1.470 & & \\
\hline \multicolumn{6}{|l|}{$5^{\text {th }}$ Assessment } \\
\hline 0 (absence of pain) & 39 & 97.50 & 03 & 7.50 & \\
\hline 1 to 3 (mild) & 01 & 2.50 & 10 & 25.00 & \\
\hline 4 to 6 (moderate) & 00 & 00 & 22 & 55.00 & \\
\hline 7 to 10 (intense) & 00 & 00 & 05 & 12.50 & \\
\hline Total & 40 & 100.00 & 40 & 100.00 & * 0.001 \\
\hline Average & 0.03 & & 4.43 & & \\
\hline Standard deviation & 0.158 & & 1.079 & & \\
\hline
\end{tabular}

Mann-Whitney test. * Level of statistical significance $p \leq 0.05$. 
Table 5. Total score of the McGill Pain questionnaire descriptors.

\begin{tabular}{|c|c|c|c|c|c|}
\hline \multirow[b]{4}{*}{ Type of group } & \multicolumn{4}{|c|}{ McGill Pain questionnaire } & \multirow{4}{*}{$p$-value } \\
\hline & \multicolumn{4}{|c|}{ Descriptors } & \\
\hline & Sensory & Affective & Evaluative & Miscellaneous & \\
\hline & $\mathrm{n}(\%)$ & $\mathrm{n}(\%)$ & $\mathrm{n}(\%)$ & $\mathrm{n}(\%)$ & \\
\hline \multicolumn{6}{|l|}{ First assessment } \\
\hline Control & $40(100)$ & $40(100)$ & $39(97.50)$ & $40(100)$ & * 0.0001 \\
\hline Study & $22(55.00)$ & $27(67.50)$ & $27(67.50)$ & $28(70)$ & \\
\hline \multicolumn{6}{|c|}{ Second assessment } \\
\hline Control & $30(75.00)$ & $34(85.00)$ & $21(52.50)$ & $40(100)$ & * 0.0001 \\
\hline Study & $20(50.00)$ & $13(32.50)$ & $11(27.50)$ & $19(47.50)$ & \\
\hline \multicolumn{6}{|c|}{ Third assessment } \\
\hline Control & $29(72.50)$ & $11(27.50)$ & $16(40)$ & $35(87.50)$ & * 0.0001 \\
\hline Study & $7(17.50)$ & $4(10.00)$ & $5(12.50)$ & $4(10.00)$ & \\
\hline \multicolumn{6}{|c|}{ Fourth assessment } \\
\hline Control & $18(45.00)$ & $24(60.00)$ & $29(72.50)$ & $10(25.00)$ & * 0.0001 \\
\hline Study & $4(10.00)$ & $2(5.00)$ & $1(2.50)$ & $3(7.50)$ & \\
\hline \multicolumn{6}{|c|}{ Fifth assessment } \\
\hline Control & $44(88.00)$ & $44(88.00)$ & $15(30.00)$ & $15(30.00)$ & * 0.0001 \\
\hline Study & $1(2.50)$ & $00(00.0)$ & $00(00.0)$ & $1(2.50)$ & \\
\hline
\end{tabular}

Mann-Whitney test. * Level of statistical significance $p \leq 0.05$.

In a study with non-adherent Ibuprofen foam dressing, the authors concluded that this it was effective in relieving pain ${ }^{16}$. In our study, patients treated with IFD also showed significant improvement after the first week of treatment.

A study in which the authors described the characteristics of pain in patients with chronic foot ulcers, applied the numerical scale and McGill Pain Questionnaire to 90 patients. The mean pain intensity reported was 7.56 and the sensitive descriptors were more frequently used to describe the pain. The authors concluded that it is necessary for the professionals, when evaluating the patients with such wounds, to use an instrument to evaluate the pain and elaborate a care plan so that they can have an improvement in pain and quality of life ${ }^{33,34}$.

The McGill Pain Questionnaire assesses the sensory, affective, and evaluative aspects of pain, describing the patients' painful experience. The sensory- discriminative dimension evaluates the temporalspatial, mechanical and thermal aspects of pain; the affective-motivational dimension involves aspects of tension, fear, self-punishment and neurovegetative responses; and the cognitive-evaluative dimension evaluates the overall situation of the individual and represents a judgment based on sensory and affective characteristics, previous experience and the meaning of the situation ${ }^{19,20,35}$

In another study with 24 pain patients, the authors investigated the effect of non-adherent Ibuprofen foam dressing. Persistent pain in the wound presented a decrease of a mean of $6.3 \pm 2.2$ to $3.0 \pm 1.7$ after 12 hours and remained low thereafter. Pain during dressing change also declined and remained low. As we did, the authors concluded that the nonadherent Ibuprofen foam dressing reduced the pain of patients with chronic venous ulcers ${ }^{36}$. 


\begin{abstract}
Objetivo: avaliar a dor em pacientes portadores de úlcera venosa de membros inferiores que utilizaram curativo de espuma não aderente com Ibuprofeno (CEI). Métodos: estudo prospectivo de pacientes portadores de úlceras venosas de membros inferiores tratados no período de abril de 2013 a agosto de 2014. Foram utilizados os questionários Escala Numérica e Questionário de Dor de McGille, as avaliações eram feitas no momento da inclusão do paciente no estudo e a cada oito dias, totalizando cinco consultas. Os pacientes foram divididos em dois grupos: 40 no Grupo Estudo (GE), que foram tratados com CEl, e 40 no Grupo Controle (GC), tratados com curativo primário, conforme o tipo de tecido e exsudato. Resultados: na primeira consulta os pacientes de ambos os grupos relataram dor intensa. No quinto dia os pacientes do GE relataram ausência de dor e a maioria do GC relatou dor moderada. Com relação ao Questionário de Dor de McGill, a maioria dos pacientes de ambos os grupos, no início da coleta de dados, relataram sensações relacionadas aos descritores sensorial, afetivo, avaliativo e miscelânea, sendo que entre os pacientes do GE houve discreta melhora após a segunda consulta. Após a terceira consulta já não referiram os descritores citados. Os pacientes do GC manifestaram todas as sensações desses descritores até quinta a consulta. Conclusão: o curativo de espuma não aderente com Ibuprofeno é eficaz na redução da dor de pacientes portadores de úlceras venosas.
\end{abstract}

Descritores: Úlcera Varicosa. Extremidade Inferior. Medição da Dor.Ibuprofeno. Qualidade de vida. Assistência Centrada no Paciente.

\section{REFERENCES}

1. Abbade LP, Lastória S, Rollo HA. Venous ulcer: clinical characteristics and risk factors. Int J Dermatol. 2011;50(4):405-11.

2. Kanjoor JR. Venous ulcer: current concepts. Indian J Plast Surg. 2011;44(1):109-11.

3. Bergan JJ, Schmid-Schönbein GW, Smith PD, Nicolaides AN, Boisseau MR, Eklof B. Chronic venous disease. N Engl J Med. 2006;355(5):488-98.

4. Salomé GM, Almeida AS, Ferreira LM. Association of sociodemographic factors with hope for cure, religiosity, and spirituality in patients with venous ulcers. Adv Skin Wound Care. 2015;28(2):76-82.

5. Salomé GM, Alves SG, Costa VF, Pereira VR, Ferreira LM. Feelings of powerlessness and hope for cure in patients with chronic lower-limb ulcers. J Wound Care. 2013;22(6):300, 302-4.

6. Corrêa NF, Brito MJ, CarvalhoResende MM, Duarte MF, Santos FS, Salomé GM, et al. Impact of surgical wound dehiscence on health-related quality of life and mental health. J Wound Care. 2016;25(10):561-70.

7. Salomé GM, Almeida SA, Ferreira LM. Evaluation of pain in patients with venous ulcers after skin grafting. J Tissue Viability. 2014;23(3):115-20.

8. Salomé GM, de Almeida SA, de Jesus Pereira MT, Massahud MR Jr, de Oliveira CN, de Brito MJ, et al. The impact of venous leg ulcers on body image and self-esteem. Adv Skin Wound Care.2016; 29(7): 316-321.

9. Salomé GM, Blanes L, Ferreira LM. The impact of skin grafting on the quality of life and self-esteem of patients with venous leg ulcers. World J Surg. 2014;38(1):233-40.

10. Lopes CR, Figueiredo M, Ávila AM, Soares LMBM, Dionisio VC. Avaliação das limitações de úlcera venosa em membros inferiores. J Vasc Bras. 2013;12(1):5-9.

11. Pedroso RA, Celich KLS. Dor: quinto sinal vital, um desafio para o cuidar em enfermagem. Texto contexto-enferm. 2006;15(2):270-6.

12. Price P. Health-related quality of live and the patient perspective. J Wound Care. 1998;7(7):365-6.

13. González-Consuegra RV, Verdú J. Quality of life in people with venous leg ulcers: an integrative review. J Adv Nurs. 2011;67(5):926-44.

14. Nelson EA, Bell-Syer SE, Cullum NA. Compression for preventing recurrence of venous ulcers. Int J Low Extrem Wounds. 2012;11(3):235-6.

15. Douglas $V$. Living with a chronic leg ulcer: an insight into patients' experiences and feelings. J Wound Care. 2001;10(9):355-60.

16. Arapoglou V, Katsenis K, Syrigos KN, Dinakakos EP, Zalopoulos N, Tsoutsos D, et al. Analgesic efficacy of anibuprofen-releasing foam dressing compared with local best practice for pain fulexuding wounds. J Wound Care. 2011;20(7):319-20, 322-5.

17. Palao iDomenech $R$, Romanelli $M$, Tsiftsis DD, Slonková $\mathrm{V}$, Jortikka A, Johannensen $\mathrm{N}$, et al. Effect of an ibuprofen-releasing foam dressing on wound pain: a real-life. J Wound Care. 2008;17(8):342-8.

18. Jørgensen B, Friis GJ, Gottrup F. Pain and quality of life for patients with venous leg ulcers: proof of concept of the efficacy of Biatain-Ibu, a new pain 
reducing wound dressing. Wound Repair Regen. 2006;14 (3):233-9.

19. Peón $A U$, Diccini S. Dor pós-operatório em craniotomia. Rev Latino-am Enfermagem. 2005;13(4):489-95.

20. Pimenta CAM, Teixeira MJ. Questionário de dor de McGill: proposta da adaptação para a língua portuguesa. Rev Esc Enferm USP. 1996;30(3): 473-83.

21. Kalra M, Gloviczki P. Surgical treatment of venous ulcers: role of subfascial endoscopic perforator vein ligation. Surg Clin North Am. 2003;83(3):671-705.

22. Macêdo EAB, Oliveira AKA, Melo GSM, Nóbrega WG, Costa IKF, Dantas DV, et al. Characterization socio-demographic of patients with venous ulcers treated at a university hospital. J Nurs UFPE online. 2010;4 (spe):1863-67.

23. Azoubel R, Torres GV, Silva LWS, Gomes FV, Reis LA. Efeitos da terapia física descongestiva na cicatrização de úlceras venosas. Rev Esc Enferm USP [Internet]. 2010 Dec [cited 2012 Aug 26];44(4):1085-92. Disponível em: http://www. scielo.br/pdf/reeusp/v44n4/33.pdf

24. Bongiovanni CM, Hughes MD, Bomengen RW. Accelerated wound healing: multidisciplinary advances in the care of venous leg ulcers. Angiology. 2006;57(2):139-44.

25. Macedo EAB, Nogueira MIS, Torres SMSGSO, Torres GV. Efetividade da terapia compressiva na cicatrização de úlcera venosa: uma revisão da literatura. Rev Fiep Bulletin. 2009;79 (especial):344-6.

26. Uchimoto S, Tsumura K, Hayashi T, Suematsu C, Endo G, Fujii $S$, et al. Impact of cigarette smoking on the incidence of Type 2 diabetes mellitus in middle-aged Japanese men: the Osaka Health Survey. Diabet Med.1999;16(11):951-5.

27. Silva JA, Ribeiro-Filho NP. Avaliação e mensuração de dor: pesquisa, teoria e prática. Ribeirão Preto: FUNPEC; 2006.

28. Brasil. Ministério da Saúde. Portaria GM/MS n 19, de 03 de janeiro de 2002. Institui, no âmbito do Sistema Único de Saúde - SUS, o Programa Nacional de Assistência à Dor e Cuidados Paliativos [Internet]. Diário Oficial [da] República Federativa do Brasil. 2002 jan 04 [acesso 2009 ago 17]. Dis- ponível em: http://dtr2001.saude.gov.br/sas/PORTARIAS/Port2002

29. Elliott TE, Renier CM, Palcher JA. Chronic pain, depression, and quality of life: correlations and predictive value of the SF-36. Pain Med. 2003;4(4):331-9.

30. Oliveira PFT, Tatagiba BSF, Martins MA, Tipple AFV, Pereira LV. Avaliação da dor durante a troca de curativo de úlceras de perna. Texto Contexto Enferm. 2012;21(4):862-9.

31. Woo KY, Sibbald RG. The improvement of wound-associated pain and healing trajectory with a comprehensive foot and leg ulcer care model. J Wound Ostomy Continence Nurs. 2009;36(2):184-91.

32. Cruz HM, Pimenta CA, Dellarozza MS, Braga PE, Lebrão ML, Duarte YA. Quedas em idosos com dor crônica: prevalência e fatores associados. Rev Dor. 2011;12(2):108-14.

33. Gonçalves ML, de Gouveia Santos VL, de Mattos Pimenta CA, Suzuki E, Komegae KM. Pain in chronic leg ulcers. J Wound Ostomy Continence Nurs. 2004;31(5):275-83.

34. Dutra RA, Salomé GM, Leal LM, Alves MG, Moura $J P$, Silva AT, et al. Cost comparison of pressure ulcer preventive dressings: hydrocolloid dressing versus transparent polyurethane film. J Wound Care. 2016; 25(11):635-40.

35. Vilela LHR, Salomé GM, Pereira RC, Ferreira LM. Pain assessment in patients with venous leg ulcer treated by compression therapy with unnas boot. J Tissue Sci Eng. 2016;7:2.

36. Jørgensen B, Gottrup F, Karlsmark T, Bech-Thomsen $N$, Sibbald RG. Combined use of an ibuprofen-releasing foam dressing and silver dressing on infected leg ulcers. J Wound Care. 2008;17(5):210-4.

Received on: 02/10/2016

Accepted for publication in: 15/12/2016

Conflict of interest: None.

Source of financing: none.

Mailing address:

Geraldo Magela Salomé

E-mail: salomereiki@univas.edu.br geraldoreiki@hotmail.com.br 